\title{
Lack of Swelling and \\ Shrinking of Pityrosporum ovale in Media of Different Osmotic Pressures and its Relationship with Survival in the Relatively Dry Conditions of the Scalp
}

\author{
BY JANET BROTHERTON \\ Unilever Research Laboratory, 455 London Road, Isleworth, Middlesex
}

(Accepted for publication 21 March 1967)

\begin{abstract}
SUMMARY
Pityrosporum ovale did not show the normal swelling and shrinking such as is undergone by Saccharomyces cerevisiae in media of different osmotic pressures. Pityrosporum ovale shrank slightly in media below 0.33 osmolar and remained at constant volume between 0.33 and 3.4 osmolar, while $S$. cerevisiae swelled below 0.10 osmolar and shrank markedly and progressively from 0.33 to 3.4 osmolar. The resistance of $P$. ovale to this effect is believed to be associated with its survival on the scalp in an environment low in water and high in salt from sweat, and to be a property of the remarkable construction of its cell wall as revealed by electron microscopy.
\end{abstract}

\section{INTRODUCTION}

When swabs are taken of human skin and scalp, large numbers of bacteria, mainly micrococci, can be cultivated (Pachtman, Vicker \& Brunner, 1954). There are two main mechanisms whereby bacteria are eliminated from the skin surface, namely dehydration and the germicidal activity of unsaturated fatty acids secreted in the sebum. The two mechanisms have been found to be effective separately, according to the species of bacteria (Ricketts, Squire \& Topley, 1951). However, the scalps of a significant proportion of the population also support large numbers of the lipophilic yeast, Pityrosporum ovale, which has often been associated with dandruff (Benham, 1945; Spoor, Traub \& Bell, 1954). This organism was originally grown on commercial oleic acid and is resistant to the fungicidal properties of unsaturated fatty acids. Its survival in the almost complete absence of water is more difficult to understand. On the scalp this must mean growth and metabolism in a medium of very high osmotic pressure, as the water, but not the salts, in the sweat evaporates off. Yeast cells in common with Gram-positive bacteria cannot be plasmolysed but swell and shrink as a whole in solutions of different osmotic pressures (Mitchell \& Moyle, 1956; Ørskov, 1945).

\section{METHODS}

Pityrosporum ovale $9265 / 3$, which had originally been isolated from a human scalp in this laboratory and which is indistinguishable morphologically and biochemically from $P$. ovale type cultures 3073 and 3074 obtained from the London School of Hygiene and Tropical Medicine, was maintained on Littman ox-gallagar slopes (Oxoid). Bulk 
cultures were prepared at $37^{\circ}$ with shaking in a medium made up from: $3 \mathrm{mg}$. palmitic acid, $8 \mathrm{ml}$. $0.0224 \mathrm{M}$-ammonium chloride, $15 \mathrm{ml}$. salts solution and $2 \mathrm{ml}$. growthfactor solution of Schultz \& McManus (1950), $0.2 \mathrm{ml}$. trace element solution of Skerman \& Singleton (1964), $3 \mathrm{ml}$. phosphate buffer (pH 5.0; Schultz, McManus \& Pomber, I949), I ml. methionine solution containing equiv. I mg. sulphur/ml. which had been sterilized by filtration; total volume $19 \cdot 2 \mathrm{ml}$. To this was added $\mathrm{r}$ g. egg-yolk lecithin (95-100\% pure, British Drug Houses Ltd.) which served to emulsify the palmitic acid and to provide further unidentified water-soluble growth factors. The

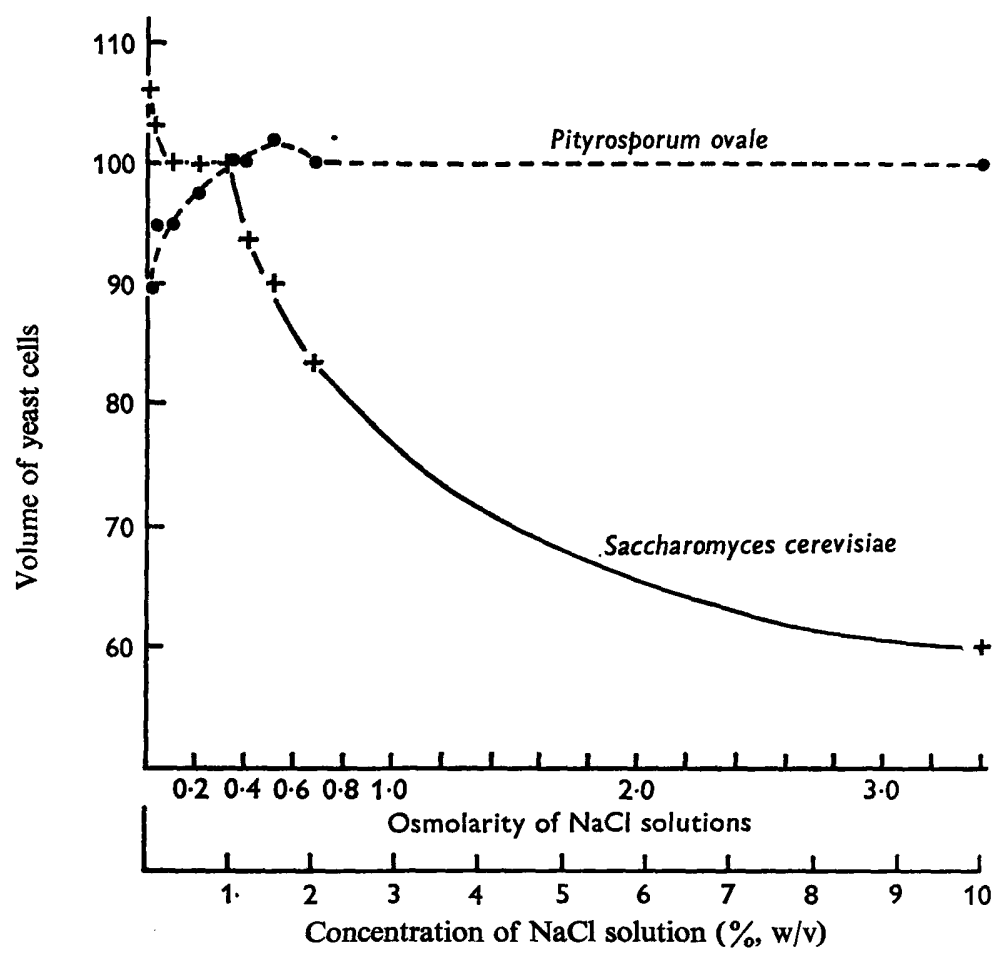

Fig. I. Swelling and shrinking of cells in media of different osmotic pressure.

same effect can be produced by sodium taurocholate (67\% pure, Difco). By the addition of I g. egg-yolk lecithin, $62 \mathrm{mg}$. dry weight of organism was produced in $48 \mathrm{hr}$ as compared with $170 \mathrm{mg}$. dry weight obtained by Benham (1945) in 4-6 weeks in a salts medium. Saccharomyces cerevisiae 456 (Unilever Research Laboratory, Colworth House, Sharnbrook, Bedfordshire) was used as a control organism. Bulk cultures were grown in malt extract broth (Oxoid) at $29^{\circ}$.

The swelling and shrinking of the organisms in saline of different osmolarities was determined by the method of Ørskov (I945). Organisms were harvested, washed three times with $15 \mathrm{ml} .0 .9 \% \mathrm{NaCl}$ solution and resuspended in $0.5 \mathrm{ml} .0 .9 \% \mathrm{NaCl}$ solution. This suspension was then placed in a standard haematocrit tube and centrifuged to constant packed-cell volume in an M.S.E. Super-Minor centrifuge with a swing-out head, at maximum speed. One minute was all that was necessary to obtain a constant packed-cell volume. The haematocrit reading was then taken immediately, since yeast 
cells are elastic. The supernatant liquid was aspirated off and the same organisms suspended in $0.5 \mathrm{ml}$. lots of $\mathrm{NaCl}$ solutions of different osmolarities and the packed cell volumes again determined.

\section{RESULTS}

The swelling and shrinking of the cells in media of different osmolarities is shown in Fig. I, for one experiment with each species of yeast. To calculate the true volume of the yeast cells by subtracting the volume of $\mathrm{NaCl}$ solution round the cells, it was assumed as an approximation that all the cells were spherical. If $r$ is the radius of the haematocrit tube $\left(1.5 \mathrm{~mm}\right.$.), the volume of cells + interstitical salt solution is $\pi r^{2} h$, where $h$ is the haematocrit reading in mm. At maximum packing, the volume taken up by $n$ spheres of radius $R$ is $6 R^{3} n=\pi r^{2} h$. Thus $R^{3} n$ can be calculated as $\pi r^{2} h / 6$. The true volumes of the cells can then be calculated as $4 / 3 \pi R^{3} n$ and expressed as a percentage of the original volume of the cells in $0.9 \% \mathrm{NaCl}$ solution.

\section{DISCUSSION}

It is seen in Fig. I that Saccharomyces cerevisiae swelled in $\mathrm{NaCl}$ solutions of very low osmotic pressure and shrank in solutions of high osmotic pressure. Between $0 \cdot$ I and 0.3 osmolar no swelling or shrinking occurred. This curve is very similar to that obtained by Ørskov (1945) who used malonamide, a solute which did not permeate into the cells. In contrast, Pityrosporum ovale shrank in $\mathrm{NaCl}$ solutions of low osmotic pressure and maintained a constant cell volume in solutions of high osmotic pressure. Thus $\boldsymbol{P}$. ovale does not exhibit the normal shrinking of yeast cells in solutions of high osmotic pressure, which is the condition that occurs on the scalp. The internal osmotic pressure of Gram-negative bacteria is about 5 atmospheres and that of Gram-positive bacteria about 20 atmospheres; that of yeast cells is also known to be high (Mitchell \& Moyle, 1956). This high internal osmotic pressure is maintained by the cell wall whose function is to strengthen the cell, permeability being regulated by the lipoprotein cytoplasmic membrane just inside the cell wall. Electron microscopy has shown that the cell walls of $P$. orbiculare (Barfatani, Munn \& Schjeide, 1964) and P. ovale (Swift \& Dunbar, 1965; Swift, 1966) are remarkable, being very thick and corrugated on the inside only in cross-section. Examination of the surface of fragmented cells has shown that these corrugations of $P$. ovale are a series of ridges which form a spiral net-work over the surface of the cell from one end to the other. Between 8 and 14 corrugations converge on the single bud scar and on the other pole of the organism. Each corrugation appears to spiral through one complete turn, i.e. through $360^{\circ}$ in traversing the length of the organism. It is concluded that these structures appear to account for the extreme rigidity of the cell wall of $P$. ovale and its survival in media of high osmotic pressure.

\section{REFERENCES}

Barfatani, M., MunN, R. J. \& SchJeide, A. O. (I964). An ultrastructure study of Pityrosporum orbiculare. J. invest. Derm. 43, 231.

Benham, R. W. (1945). Pityrosporum ovale. A lipophilic fungus. Thiamin and oxalo-acetic acid as growth factors. Proc. Soc. exp. Biol. Med. 58, 199.

Mrtchell, P. \& MoYle, J. (1956). Osmotic function and structure in bacteria, in Bacterial Anatomy, Symp. Soc. gen. Microbiol. 6, 150. 


\section{J. BROTHERTON}

ØRSKov, S. L. (1945). Investigations on the permeability of yeast cells. Acta path. microbiol. scand. 22, 523.

Pachtman, E. A., Vicker, E. E. \& Brunner, M. J. (1954). The bacteriologic flora in seborrheic dermatitis. J. invest. Derm. 22, 389.

RicketTS, C. R., SQuiRE, J. R. \& TOPLEY, E. (1951). Human skin lipids with particular reference to the self-sterilising power of the skin. Clin. Sci. ro, 89.

SCHultz, A. S. \& MCMANUS, D. K. (1950). Amino acids and inorganic sulphur as sulphur source for the growth of yeasts. Archs. Biochem. 25, 401 .

SChUltz, A. S., McManus, D. K. \& Pomber, S. (1949). Amino acids as carbon source for the growth of yeasts. Archs. Biochem. 22, $4 \mathrm{I2}$.

SKERMAN, T. M. \& SINGLETON, R. J. (1964). Sulphur nutrition of two strains of the yeast, Debaromyces kloeckeri, isolated from subantarctic soil. Can. J. Microbiol. ro, 397.

Spoor, H. J., Traub, E. T. \& BeLl, M. (1954). Pityrosporum ovale types cultured from normal and seborrheic subjects. Archs. Derm. Syph., Chicago 69, 323.

SwIFT, J. A. (1966). The electron microscopy of yeasts from the family Cryptococcaceae with particular reference to those of the Pityrosporum genus. Proc. 6th int. Congress Elect. Micro., Kyoto, Japan.

SWIFT, J. A. \& DUnBar, S. F. (1965). Ultrastructure of Pityrosporum ovale and Pityrosporum canis. Nature, Lond. 206, 174. 